\title{
The image of the foreign squatter: British and Irish youths in the Dutch city of Leiden during the 1990s - CORRIGENDUM
}

Bart van der Steen, Blerina Nimanaj and Elisa Hendriks

doi:10.1017/S0963926821000675. Published online by Cambridge University Press: 10 November 2021

The original published version of this article did not include an acknowledgements section. The information has now been added, and the online PDF and HTML versions have been updated.

\section{Reference}

van der Steen, B., Nimanaj, B., \& Hendriks, E. (2021). The image of the foreign squatter: British and Irish youths in the Dutch city of Leiden during the 1990s. Urban History, 1-23.

Cite this article: van der Steen B, Nimanaj B, Hendriks E (2022). The image of the foreign squatter: British and Irish youths in the Dutch city of Leiden during the 1990s - CORRIGENDUM. Urban History 49, 473-473. https://doi.org/10.1017/S096392682100105X

(C) The Author(s), 2022. Published by Cambridge University Press. This is an Open Access article, distributed under the terms of the Creative Commons Attribution-NonCommercial-NoDerivatives licence (https://creativecommons.org/ licenses/by-nc-nd/4.0/), which permits non-commercial re-use, distribution, and reproduction in any medium, provided the original work is unaltered and is properly cited. The written permission of Cambridge University Press must be obtained for commercial re-use or in order to create a derivative work. 